\title{
Effect of the Inclination Angle on the Defining Parameters of Chip Removal in Rotational Turning
}

István Sztankovics, János Kundrák

Institute of Manufacturing Science, Faculty of Mechanical Engineering and Informatics, University of Miskolc, H-3515 Miskolc-Egyetemváros. Hungary. E-mail: istvan.sztankovics@uni-miskolc.hu

The efficiency of the machining processes, the accuracy of the manufactured parts, and the quality of the machined surface are determined by several factors: the tool geometry, the parameters that affect the kinematic relations, and the cutting parameters. Therefore it is necessary to investigate the effect of each characteristic parameter on the technological parameters in the research of rotational turning. In this paper first we sum up the geometric and kinematic relations that affect the defining parameters of chip removal. We give an overview of the parameters which must be given in rotational turning. We briefly show the method used for the mathematic-analytic definition of these parameters. After that we determinate and analyse the alteration effect of the inclination angle on the resultant axial feed, on the theoretical arithmetic mean deviation and on the characteristic parameters of the chip cross-section.

Keywords: rotational turning, chip removal characteristics, inclination angle

\section{Acknowledgments}

This research was (partially) carried out in the framework of the Center of Excellence of Innovative Engineering Design and Technologies at the University of Miskolc.

The work was presented by the support of the Hungarian Scientific Research Fund (Number of Agreement: OTKA K 78482), which the authors greatly appreciate.

\section{References}

[1] BYRNE, G., DORNFELD, D., DENKENA, B. (2003). Advancing Cutting Technology. In: CIRP Annals - Manufacturing Technology, Vol. 52, Issue 2, pp. 483-507.

[2] SHAW, M. C. (2005). Metal Cutting Principles, 651 p., Oxford University P, New York,

[3] BRECHNER, C., ESSER, M., WITT, S. (2009). Interaction of manufacturing process and machine tool. In: CIRP Annals - Manufacturing Technology, Vol 58, pp 588-607

[4] MRKVICA, I., NESLUŠAN, M., KONDERLA, R., JANOŠ, M. (2012). Cutting ceramic by turning of nickel alloy Inconel. In: Manufacturing Technology, Vol 12, No 13, pp.178-186

[5] KAÇAL, A., YILDIRIM, F. (2013). High Speed Hard Turning of AISI S1(60WCrV8) Cold Work Tool Steel. In: Acta Polytechnica Hungarica, Vol. 10, No. 8, pp. 169-186

[6] GALANIS, N. I., MARKOPOULOS, A. P., GIANNAKOPOULOS, I. D., MANOLAKOS, D. E. (2013). Manufacturing of Femoral Heads from Ti-6Al-4V Alloy with High Speed Machining: 3D Finite element Modelling and Experimental Validation. In: Manufacturing Technology, Vol 13, No 4, pp.437-444

[7] ČILLIKOVÁ, M., NESLUŠAN, M., MIČIETOVÁ, A., MRÁZIK, J. (2012). Study of deformation Processes after Hard turning through Acoustic Emission. In Manufacturing Technology, Vol 12, No 12, pp.13-17

[8] NOVAK, M. (2012). Surfaces with high precision of roughness after grinding. In: Manufacturing Technology, Vol 12, No 12, pp.66-70

[9] MADL, J. (2012). Surface Properties in Precise and Hard Machining. In: Manufacturing Technology, Vol 12, No 13, pp. 158-166

[10] JERSÁK, J., VRKOSLAVKOVÁ, L. (2013). The Influence of Process Fluids ont he Properties of the Surface Layer of Machined Components. In: Manufacturing Technology, Vol 13, No 4, pp.466-473

[11] VARGA, G. (2014). Effects of Technological Parameters on the Surface Texture of Burnished Surfaces.In: Key Engineering Materials, Vol. 581: Precision Machining VII, pp: 403-408

[12] TSCHÄTSCH, H., DIETRICH, J. (2011). Praxis der Zerspantechnik, 393 p., Vieweg+ Teubner Verlag, Wiesbaden

[13] MBN 31007-7 (2002). Patent by Daimler Chrysler AG, Stuttgart 
[14] KLIMENKO, S. A., MANOKHIN, A. S. (2009). Hard "Skiving” Turning. In: Journal of Superhard Materials, Vol 31, No 1, pp. 58-74

[15] ARMAREGO, E. J. A., KARRI, V., SMITH, A. J. R. (1994). Fundamental studies of driven and self-propelled rotary tool cutting processes - I. Theoretical investigation. In: International Journal of Machine Tools and Manufacture, Vol 34, No 6, pp. 785-801

[16] KISHAWY, H. A., WILCOX, J. (2003). Tool wear and chip formation during hard turning with self-propelled rotary tools. International Journal of Machine Tools and Manufacture, Vol 43, pp. 433-439

[17] VASILKO, K., PILC, J. (2013). New Technologival Knowledge of the Rotary Turning Tool. In Manufacturing Technology, Vol 13, No 4, pp.471-475

[18] SCHULZ, H. (1990). High Speed Turn-Milling - A new precision manufacturing technology for the machining of rotationally symmetrical workpieces. In: CIRP Annals Vol 39, No 1, pp. 621-640

[19] SAVAS, V., OZAY, C. (2007). Analysis of the surface roughness of tangential turn-milling for machining with end milling cutter. Journal of Materials Processing Technology, Vol 186, pp. 279-283

[20] J.G. Weisser Söhne GmbH \& Co: Patent Anmeldung, St.Georgen, Germany, 2004

[21] KLOCKE, F., BERGS, T., DEGEN, F. (2013). Presentation of a novel cutting technology for precision machining of hardened, rotationally symmetric parts. In: Production Engineering, Vol. 7, Issue 2-3, pp. 177-184

[22] Rotationsdrehen WELLEN - schneller geht's nicht! (2014) from http://www.mas-tools.de

[23] SZTANKOVICS, I., KUNDRÁK, J. (2013). Theoretical Value of Total Height of Profile in Rotational Turning. In: Applied Mechanics and Materials, Vol. 309, pp. 154-161

[24] PEREPELICA, B. A. (1981). Otobrazsenija affinnogo prosztransztva v teorii formoobrazovanija poverhnosztej rezaniem. Harkov, p. 152, 1981

[25] KUNDRÁK, J., GYÁNI, K., DESZPOTH, I., SZTANKOVICS, I. (2012). Technology planning of hard turning in case of rotational feed. In: Proceedings of International Conference on Innovative Technologies, pp. 295-299

[26] SZTANKOVICS, I. (2013). Theoretical Value of Arithmetic Mean Deviation in Rotational Turning. In: Müszaki Tudományos Füzetek - Fiatal Müszakiak Tudományos Ülésszaka XVIII., pp. 391-394, (in Hun.)

[27] SZTANKOVICS, I., KUNDRÁK, J. (2014). Determination of the Chip Width and the Undeformed Chip Thickness in Rotational Turning. In: Key Engineering Materials, Vol. 581: Precision Machining VII, pp: 131-136 